\title{
GEO-ENVIRONMENTAL ANALYSIS OF REMOTE SENSING DATA: A CASE STUDY OF OHAFIA AREA, SOUTHEASTERN NIGERIA
}

OKEREKE, C. N*. IKORO, D. O.*, and UGWU, O. J.***

*Department of Geology, Federal University of Technology, Owerri, Imo State, **Department of Surveying and Geoinformatics, Federal University of Technology, Owerri, Imo State, Nigeria

Corresponding author: ikorodiugoo@gmail.com

The main objective of this paper is to integrate the distribution of gully sites in the Ohafia area of Southeastern Nigeria using remote sensing technique. The Landsat thematic mapper (TM) data of parts of Ohafia was studied with objective of identifying the structures associated with the area and to infer their influence on the gully erosion initiation and propagation. The Landsat TM data was processed using the ILWIS 3.2 Academic and ERDAS software packages.In the course of this study, activities such as laterite excavations, bad farming practices, unplanned road construction and urbanization, wood harvesting for fuel and bush burning to clear lands for farming, among others were identified as factors that cause gully erosion. These activities, coupled with annual flooding from rain water were causing havoc and untold hardship as gullies continue to develop and expand rapidly in the area. Utilizing the opportunities offered by Remote Sensing, this research project came up with vital spatial datasets on the spatial distribution, development and impact of gully erosion in Southeastern Nigeria.The composite images gotten reveal the drainage pattern of the study area to be dendritic.The area is affected by tectonic activities on the geologic formation of the area is responsible for the increasing gully and landslide in the area. Lineament trend in the area correlated well with the measured strokes of the geologic formations. The study revealed that gully developments are more pronounced in areas with high terrain undulation and therefore affected areas should be reclaimed by extensive afforestation and other agricultural programme.

Keywords: Gully erosion, Remote Sensing, Landsat Thematic Mapper.

\section{INTRODUCTION}

The study of erosion has become very essential in order to prevent or mitigate further devastating effects it has caused. Erosion has been defined as the physical removal of soil and rock particles from the surface of the earth by natural processes such as wind or flow of water and then deposited in other locations (Okereke et al., 2012). This can also be explained to be the physical removal of materials (soil particles) from one place to another. It is an accelerated process under which soil is bodily displaced and transported away faster than it can be formed. Soil erosion is a natural process caused by water, wind and ice, and is a serious land degradation problem globally (Ritchie, 2000).It usually manifests itself in three forms: Sheet erosion, rill erosion and gully erosion (Okeke and Enwelu, 2010).

While erosion is a natural process, human activities have dramatically increased (by 10-40 times) the rate at which erosion is occurring globally (WBDMD, 2018). Overall, soil is being lost from agricultural areas 10 to 40 times faster than the rate of soil formation jeopardizing humanity's food security (Pimentel and Burgess, 2013).Excessive erosion causes problems 
such desertification, decrease in agricultural productivity due to land degradation, sedimentation of waterways and ecological collapse due to loss of the nutrient rich upper soil layers. Water and wind erosion are now the two primary causes of land degradation; combined, they are responsible for $84 \%$ of the degradation acreage, making excessive erosion one of the most significant global environmental problems we face today (WBDMD, 2018).In addition, the soil erodibility index is subjective to both physical and chemical properties of soil (Osadebe and Akpokodje, 2007).However, gully erosion is the most prominent feature in the landscape of Imo State and every community in the State faces the imminent dangers that are caused by the ever-increasing gullies found in area. Gully erosion is described as an incised cut step-sided channel, with an eroding head cut and slumping sidewalls (Okereke et al., 2012). These develop because of a decrease in the erosion resistance of the land surface or increase in the erosion forces acting on the land surface. Gullies can also be defined as erosion features that are too deep to be ploughed with ordinary farm equipment; although there has not been specific upper limit to the size of gullies, they typically range in size from $0.5 \mathrm{~m}$ to as much as $30 \mathrm{~m}$ deep (Soil Science Society of America, 1996).

Remote sensing is the process of collecting information of an object without contact with the object. Remote sensing is applied for purposes such as mineral exploration, land use land cover analysis, urban planning, geomorphology, environmental study,disaster study and management and water resources analysis. The study of phenomena using remote sensing technique involves two processes, which are data acquisition and data analysis (Subramanian, 2010).

Remote sensing makes it possible to collect data on dangerous or inaccessible areas. Remote sensing applications include monitoring deforestation in areas such as the Amazon Basin, glacial features in Arctic and Antarctic regions, and depth sounding of coastal and ocean depths. Remote sensing instruments such as artificial satellites are capable of providing quantitative and qualitative information about objects and phenomena such as gully erosion. Photographic interpretation and remote sensing are presently both being employed extensively as tools in management and planning are both used extensively in the preservation of our environment and natural resources (Wolf et al., 2014).

Orbital platforms collect and transmit data from different parts of the electromagnetic spectrum, which in conjunction with larger scale aerial or ground-based sensing and analysis provides researchers with enough information to monitor trends such as El Niño and other natural long and short term phenomena. Other uses include different areas of the earth sciences such as natural resource management, agricultural fields such as land usage and conservation, and national security and overhead, ground-based and stand-off collection on border areas.

Through maximization of the spectral, spatial and temporal resolution of a satellite sensor, remote sensing techniques can map gullies with less expert knowledge, time and cost, and provide the appropriate quantitative information necessary for combating erosion. In general, these three resolution types allow for characterization of the gullies and the surrounding landscape from the local to global spatial scales (Wilkie and Finn, 1996). Spatial resolution is "a measure of the linear separation between two objects that can be resolved by a remote sensing system" which dictates the size of the smallest possible feature that can be detected in the satellite image (Wilkie and Finn, 1996,Jensen, 2005). According to Subramanian (2010), spatial resolution can also be defined as the ability of the remote sensing system to record spatial details. The spatial coverage offered by certain satellite imagery is much larger than a conventional photograph, for example, "it can take 5000 conventional vertical aerial photographs obtained at a scale of 1:15000 to fit the geographic extent of a single Landsat image" (Jensen, 2005). Such a large spatial coverage allows for a direct perspective of the 
regional mix of the gully erosion process (regionalization), provided that the gullies are large enough to be detected by the spatial resolution of the images (Giordano and Marchisio, 1991). The spectral resolution (dimension and number of wavelength regions of a sensor system) allows for feature extraction methods for gully mapping, for example ideal band combinations, vegetation indices and classification algorithms. Such techniques combined with the repetitive coverage of a particular area by satellite systems (temporal resolution) can lessen the time and cost required to produce a gully erosion map. This offers the possibility of monitoring the extent and evolution of gully erosion.

\section{GEOLOGY OF OHAFIA AREA AND ITS ENVIRON}

The study area -Ohafia and its environ, is located on latitudes 530 and $545 \mathrm{~N}$ and longitudes 730 and 800 E. Ohafia and its environ is located in the Afikpo basin which evolved after the Santonian tectonic activity. This area is underlain by the Nkporo, Mamu, Ajali and Nsukka which are the Upper Cretaceous Formations of the basin while the Tertiary formations include the Paleocene Imo Shale, Eocene Ameki/ Nanka, and Oligocene-MioceneThe formations are conformable and have a general E-W to NNE-SSW dips of between $8{ }^{0}$ to $25^{0}$. Nkporo Shale group was deposited during the Campanian. The group consists of blue-to-dark grey friable shales with occasional thin beds of limestone and sandstones. These formations rarely outcrop and information about them comes mainly from boreholes and they exhibit frequent sharp facies changes. Mamu Formation was deposited during the Maastrichtian and was previously known as the "Lower Coal Measures". The Formation consists of sandstones, shales, mudstone and sandy shales, with coal seams at several levels.

The Ajali Formation was deposited during the Maastrichtian. This Formation was previously known as the "False Bedded Sandstones", consisting of thick friable, angular to sub-rounded quartz grains, poorly sorted sandstones, typically white in color and sometimes iron stained with white thin bands of mudstone and shale occurring at intervals. The Ajali Formation is often overlain by a considerable thickness of red earth, which consists of red, earthy sands, formed by the weathering and ferruginization of the formation. The Ajali sand is the major water-bearing formation in the area. Nsukka Formation was deposited during the Upper Maastrichtian. The formation consists of alternating succession of sandstones, dark shales, and sandy shale, with thin coal seams at various horizons. The Nsukka Formation has a very strong iron cap that prevents erosion while Mamu and Nkporo have swelling clays that would minimize erosion. Thus the agent of erosion in this area is the Ajali Sandstone Formation. The gullies in this study were all located on the areas of exposure of Ajali Sandstone.

The SRTM image data and the topographic sheets were used to generate contour data at about $10 \mathrm{~m}$ interval. From the contour data, point files with the coordinates and elevations were generated and imported into Surfer 8 software, where the DEMs (Digital Elevation Models) were generated. The enhanced image window for each of the concerned State was furthermore draped over the corresponding DEM to generate the 3D - Digital Terrain Model with much more enhanced surface information. Although the scale of generation was medium, due to the resolution of the satellite images used, the results display very well various geomorphologic characteristics that facilitate the development and formation of gullies.

However, there is no clearly defined upper limit on the dimensions of gullies (Poesen et al., 2002). Gullies typically range in incision depth of 0.5-30 m, and as wide as $80 \mathrm{~m}$ (Garland et $a l .$, 1999).Gully length is less frequently reported when gully systems are integrated with drainage networks and the channels can reach lengths of up to several kilometers (Garland et al., 1999) 


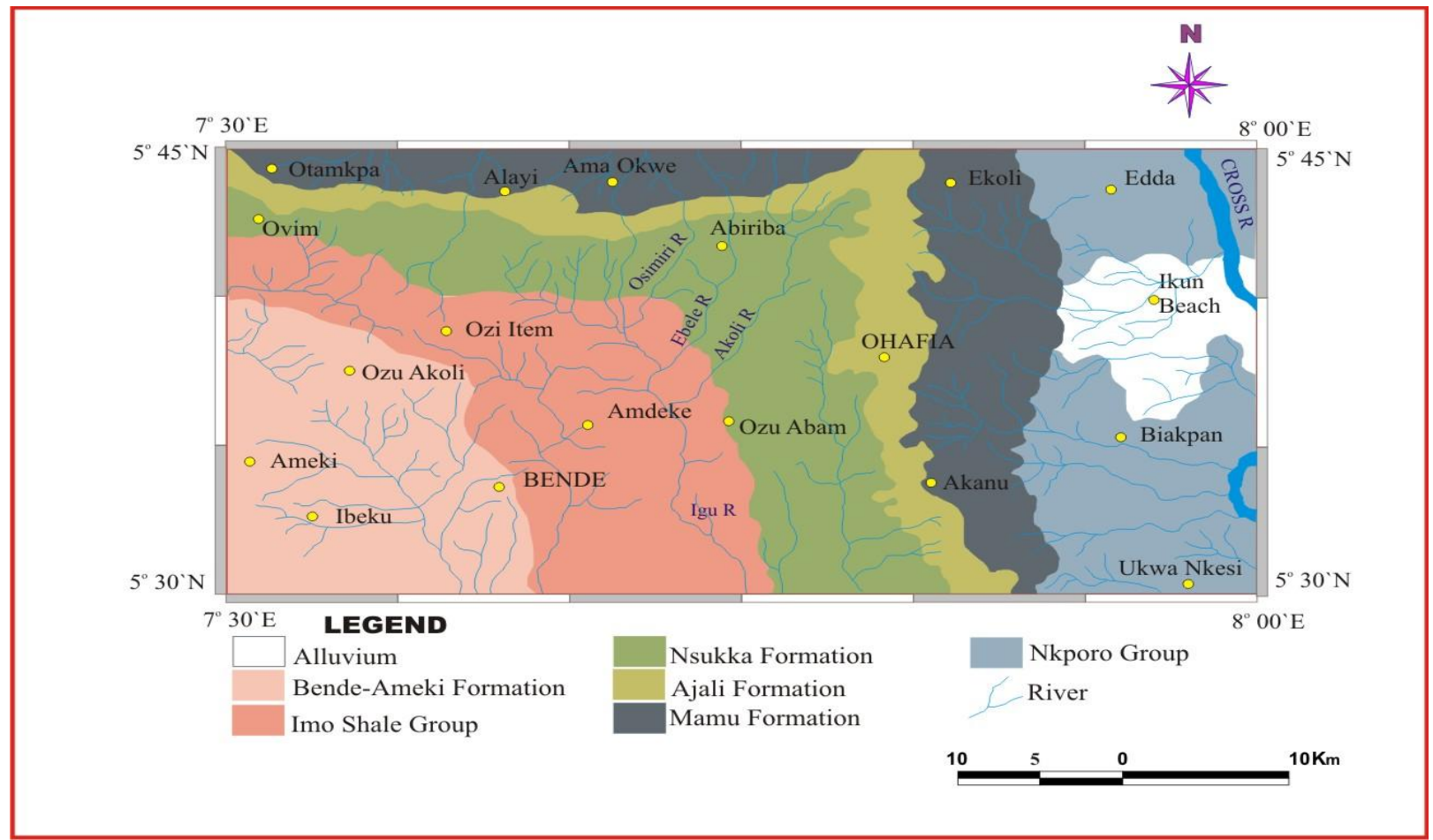

Fig. 1: Geological Map of the Study Area

\section{Interactions of Gully Controlling Factors}

For gully mapping, it is important to recognize the dominant environmental factors that control erosion because this will determine the rate of the gully erosion process and thus the timescale needed for map updating. Environmental factors that control gully erosion include bedrock type, soil, climate, topography, vegetation and human activity (Botha, 1996). The rate of gully development and its location is highly dependent on the complex interactions among these facts.

Sometimes, gullies occur more frequently on soils underlain by shale (Berjaket al., 1986) or dolerite (Bader, 1962) as these rocks develop into fine grained soils once weathered. Additionally, the presence of unconsolidated sediments that are high in silt (colluvial and alluvial sediments) coincides with most of the areas of gully erosion in KwaZulu-Natal (Botha et al. (1994) as these sediments generally have higher run-off rates (due to lower permeability) and can easily detach (Terrence et al., 2002). Such sediments exist as multilayers in gully sidewalls and are often marked by the embedment of stone lines (FelixHenningsen, et al., 1997).

Climate can influence the rate of gully erosion directly, through precipitation, temperature, and indirectly, through the conditions that influence the vegetation cover. Rainfall is a major driving force of many erosional processes in South Africa (Moore, 1979) because the amount of detached soil is directly proportional to rainfall intensity (Van Dijk et al., 2002). Vegetation cover and type are affected by Rainfall which moderates the erosion intensity of an area. In KZN, gullies have been mostly located in areas that are mild semi-arid with very cold to warm temperatures (Scotney, 1978) because climatic areas of this nature are sparsely vegetated. Liggitt (1988) found that in some areas of KZN gullying decreases significantly where mean annual rainfall exceeds $800 \mathrm{~mm}$. This was further confirmed by Liggitt and Fincham (1989), in their study of the Mfolozi catchment where rainfall less than $900 \mathrm{~mm}$ per annum experienced greater erosion. These conclusions demonstrate the complex interactions of climate on gully erosion. An area with high mean annual rainfall promotes lush vegetation 
that secures the soil by reducing surface runoff, increasing the infiltration rate, root deepening and increasing organic matter, thus making it more resistant to gully erosion (Laker, 2000). Conversely relatively warmer, drier areas limit the growth of which exposes the soil thus making the area more prone to gully erosion.

Slope steepness, length and shape are some important topographical properties that control the erosion processes. Topography is an important determinant of erosion potential since it controls the energy gradients. Gullies can develop on very gentle to steep slopes, but are most numerous on strongly sloping land (Bergsma, 1974). However, in contrast, Liggitt and Fincham (1989) found gully erosion in KZN to be inversely related to slope steepness. Where slope gradients are less than $10^{\circ}$ gullies occur most frequently (Liggitt and Fincham, 1989) because of the increase in runoff resulting from land clearing, overgrazing, cultivation, and stream channelization, which are more common on gentle slopes. Furthermore, commercial cultivation is done on flatter areas making them more susceptible to gully erosion. In certain parts of South Africa, a strong spatial correlation exists between abandoned cultivated land and gully erosion (Kakembo and Rowntree, 2003). This has been attributed to the little basal cover offered by the type of vegetation that grows when cultivation of fields is no longer active, making the land more vulnerable to erosion by overland flow (Sonneveld et al., 2005). Improvements in spatial mapping of gullies can help identify the factors controlling gully erosion through multi-temporal analysis.

\section{METHODOLOGY}

Firstly, a reconnaissance survey was carried out in different, selected gully erosion sites within the Ohafia environ. Various stops were made at the different gully sites. The outcrops were observed and analyzed visually. The positions (latitude, longitude and elevation) of the gully sites measured using a Global Positioning System (GPS) are listed below:

\section{Site Locations}

Location 1: Between Igbere and Abiriba:

Latitude: $05^{\circ} 43.151^{\prime} \mathrm{N}$

Longitude: $07^{0} 40.826^{\prime} \mathrm{E}$

Elevation: $540 \mathrm{ft}$.

Location 2: North West of Abiriba

Latitude: $05^{0} 43.017^{\prime} \mathrm{N}$

Longitude: $07^{0} 42.514^{\prime} \mathrm{E}$

Elevation: $606 \mathrm{ft}$.

Orientation of gully:

Location 3: Amaekpu village

Latitude: $05^{0} 39.9^{\prime} \mathrm{N}$

Longitude: $07^{0} 49.293^{\prime} \mathrm{E}$

Elevation: $550 \mathrm{ft}$.

Data Processing: The Landsat data used were acquired from the National Space Research and Development Centre Agency (NSRDA). The image was obtained using Landsat ETM sensor with band combination 2, 3 and 4 with a resolution of $30 \mathrm{~m}$. The following color codes were used, red for vegetation, black for rock outcrops, gray/white for bare/exposed surfaces and blue for water bodies. The processing of the Landsat images were done using ILWIS 3.2 Academic and ERDAS imaging software. These software have the capacities of carrying out various data enhancement techniques such as linear enhancement, statistical analysis, principal component analysis and normalized difference vegetation index. The image enhancement operations were carried out for better visual interpretation, to reduce noise 
distortion in the image prior to a multi-band image classification and to detect line features in the satellite image to aid structural interpretation. The images were geo-referenced to a Universal Transverse Mercator (UTM) grid using the software to allow compatibility and comparison with other data sets.

\section{DISCUSSION/INTERPRETATION OF RESULT}

An extensive data processing and reduction were carried out on Landsat data which resulted to the generation of the following maps: Digital Elevation Model (DEM) map, lineament and lineament density map, the Normalized Difference Vegetation Index (NDVI), the False Color Composite Maps and the Rose Diagram. The output of NDVI is a measure of vegetation richness of an area. Values of NDVI can range from -1.0 to 1.0, but values less than zero typically do not have any ecological meaning. Low NDVI values mean there is little difference between the red and near infra-red (NIR) signals. This happens when there is little photosynthetic activity or when there is just very little NIR light reflectance (that is, water reflects very little NIR light from the NDVI of +0.33 to -0.49 , which shows unhealthy vegetation. The area was much earlier in time protected by dense forest which the inhabitants removed in the process of urbanization and agricultural activities leading to an exposure of the fragile soil to the heavy downpour and concentrated runoff of the area. The high speed of the soil surface runoff culminates in rapid washing away of the soil surface weakening the soil strata which is the chief cause of gullies in the area. This fact is attested to by the findings of Egboka and Nwankwo (1982), Adesida et al.(1977), Igbokwe et al.(2003).

The following images below were taken from different locations in my area of study;

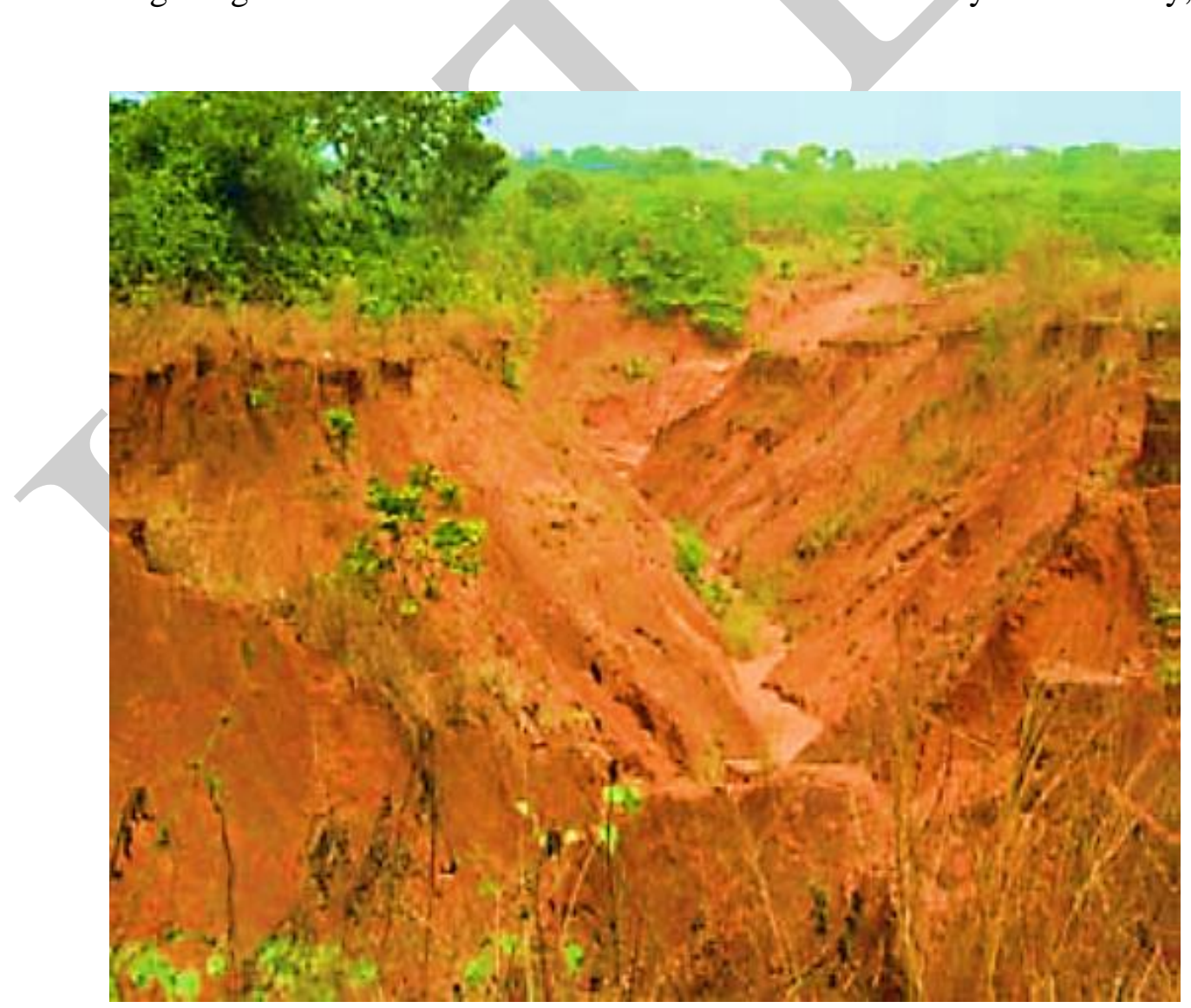

Plate 1: Ofan Erosion Site in Uzuakoli 
DOI : https://dx.doi.org/10.26808/rs.ed.i9v2.03

International Journal of Emerging Trends in Engineering and Development

Available online on http://www.rspublication.com/ijeted/ijeted_index.htm

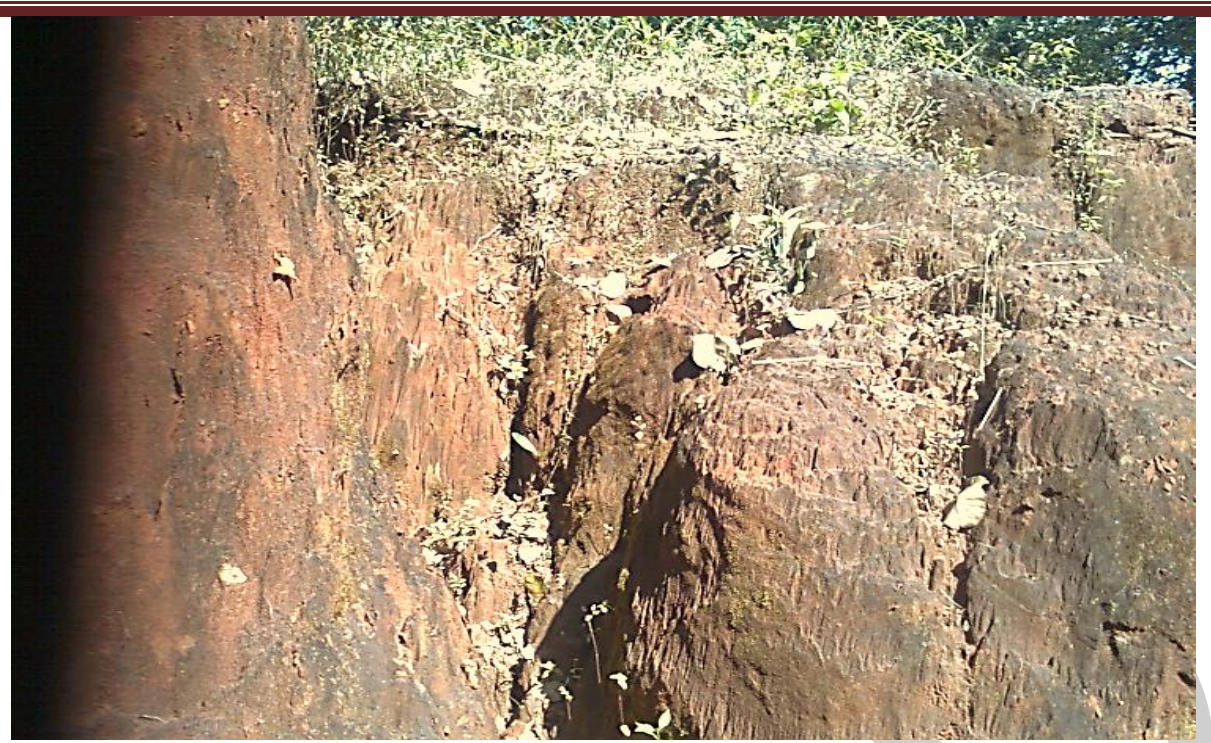

Plate 2: A plate along Ebem-Asaga Road

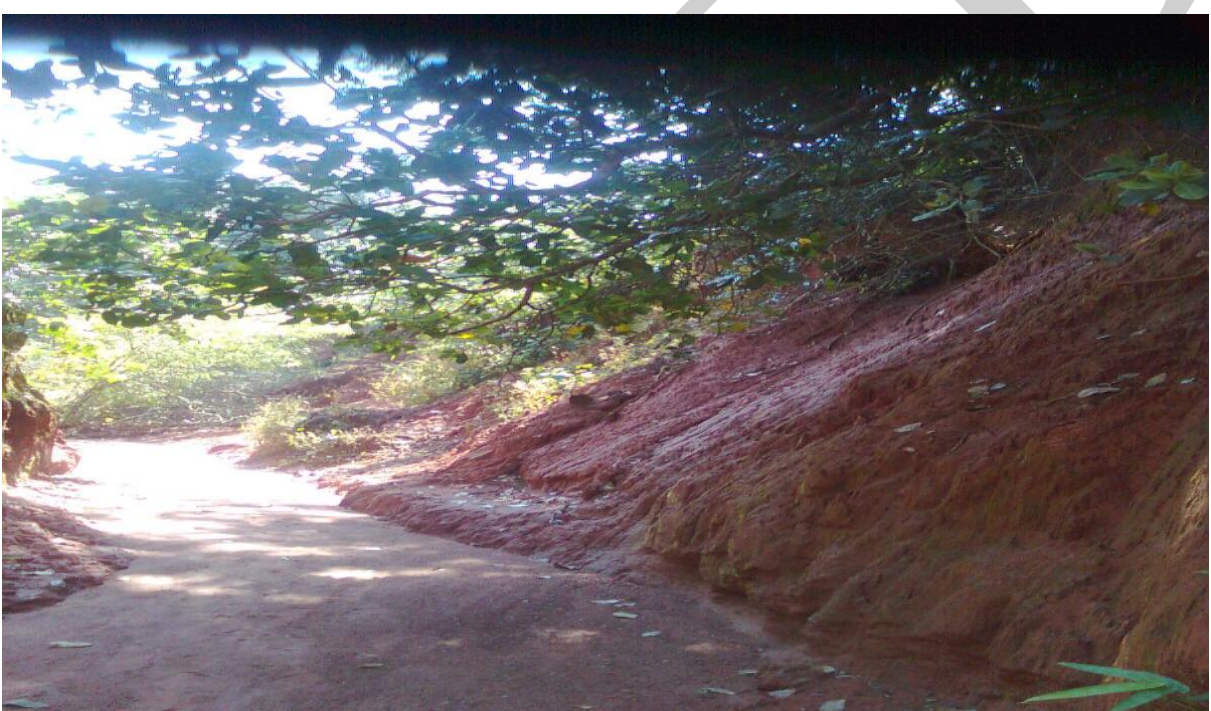

Plate 3: A plate located in Ohutu Town

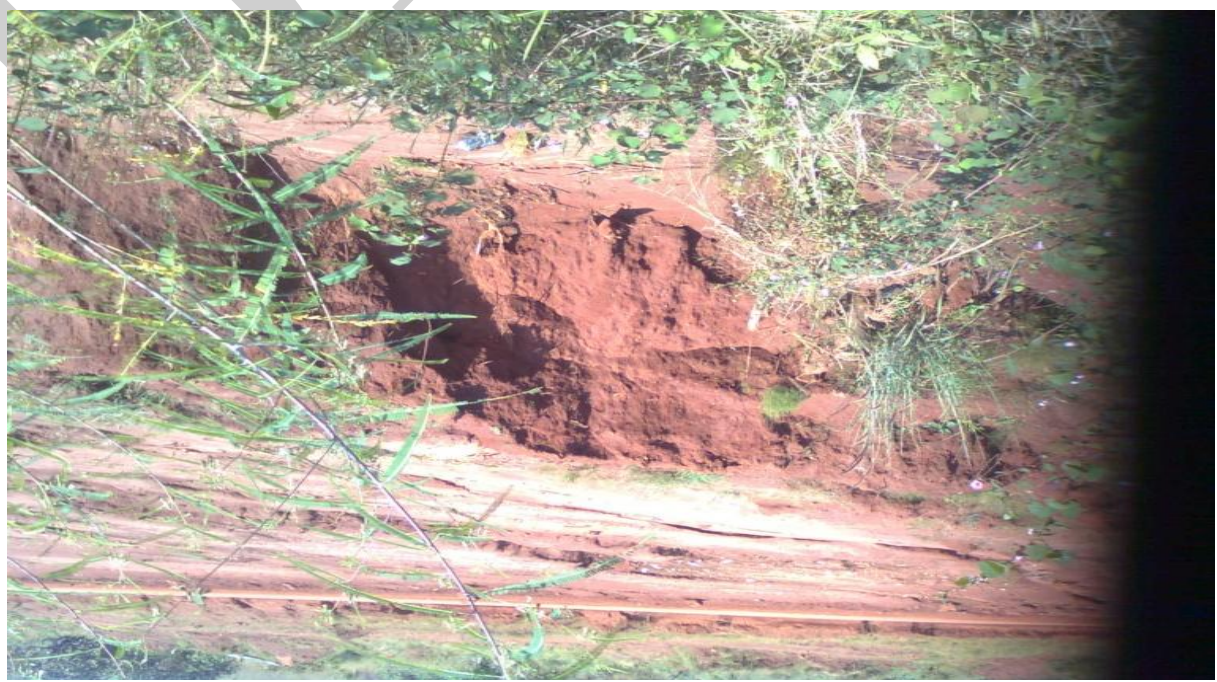

Plate 4: A plate located at Ndibem. The area is underlain by a sandstone unit of Nkporo Formation 

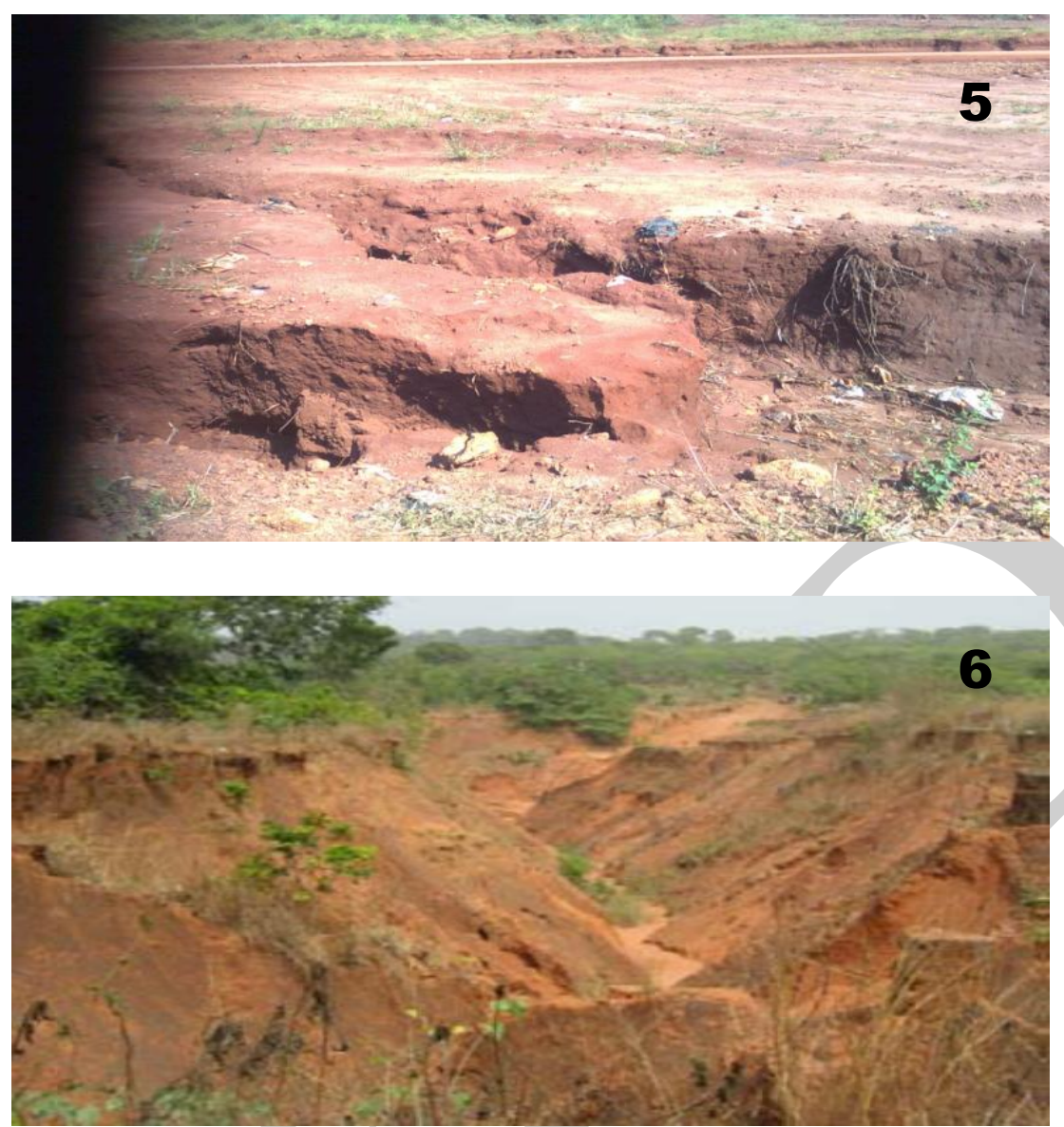

\section{Plates 5 \& 6: Active Gully Sites in Ohafia Area}

The Normalized Difference Vegetation Index (NDVI) is an index of plant "greenness" or photosynthetic activity, and is one of the most commonly used vegetation indices. Vegetation indices are based on the observation that different surfaces reflect different types of light.

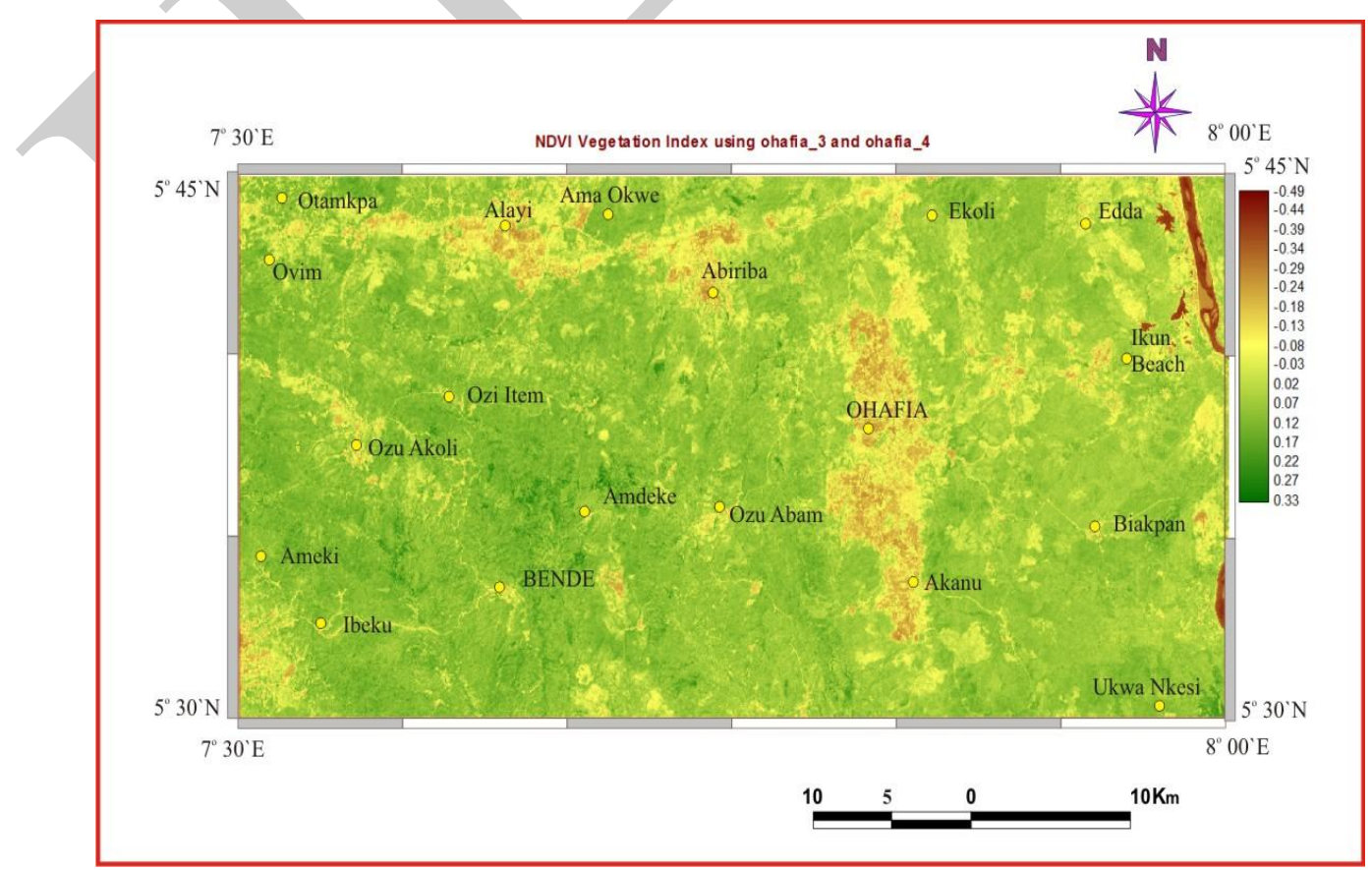

Fig.3: Normalized Different Vegetation Index (NDVI) of the study area 
In the RGB 742, 532, 432,321 false colored composite maps, the green areas represent the active vegetation while the blue areas represents the waters, the grey areas represents the ground surface or bare rocks. The composite images reveal the drainage pattern of the study area to be dendritic. The dendritic drainage pattern of the area trends in the NE-SW direction is associated with trench branching tributaries joining the main stream at acute angle and this pattern shows up on homogeneous, uniform soil and rock materials mostly in soft sedimentary rocks and old dissected coastal plains (Howard, 1967). The dendrite pattern reveals a lithological, structural and topographical homogeneity of the study area. This occurs on homogenous gentle, uniformly sloping sedimentary surfaces whose main collector streams may indicate a fault or fracture. The geological interpretation of the Landsat imagery revealed a number of lineaments and mega-lineaments over $15 \mathrm{~km}$ in size trending in the NE-SW, much less in NW-SE \& N-S.
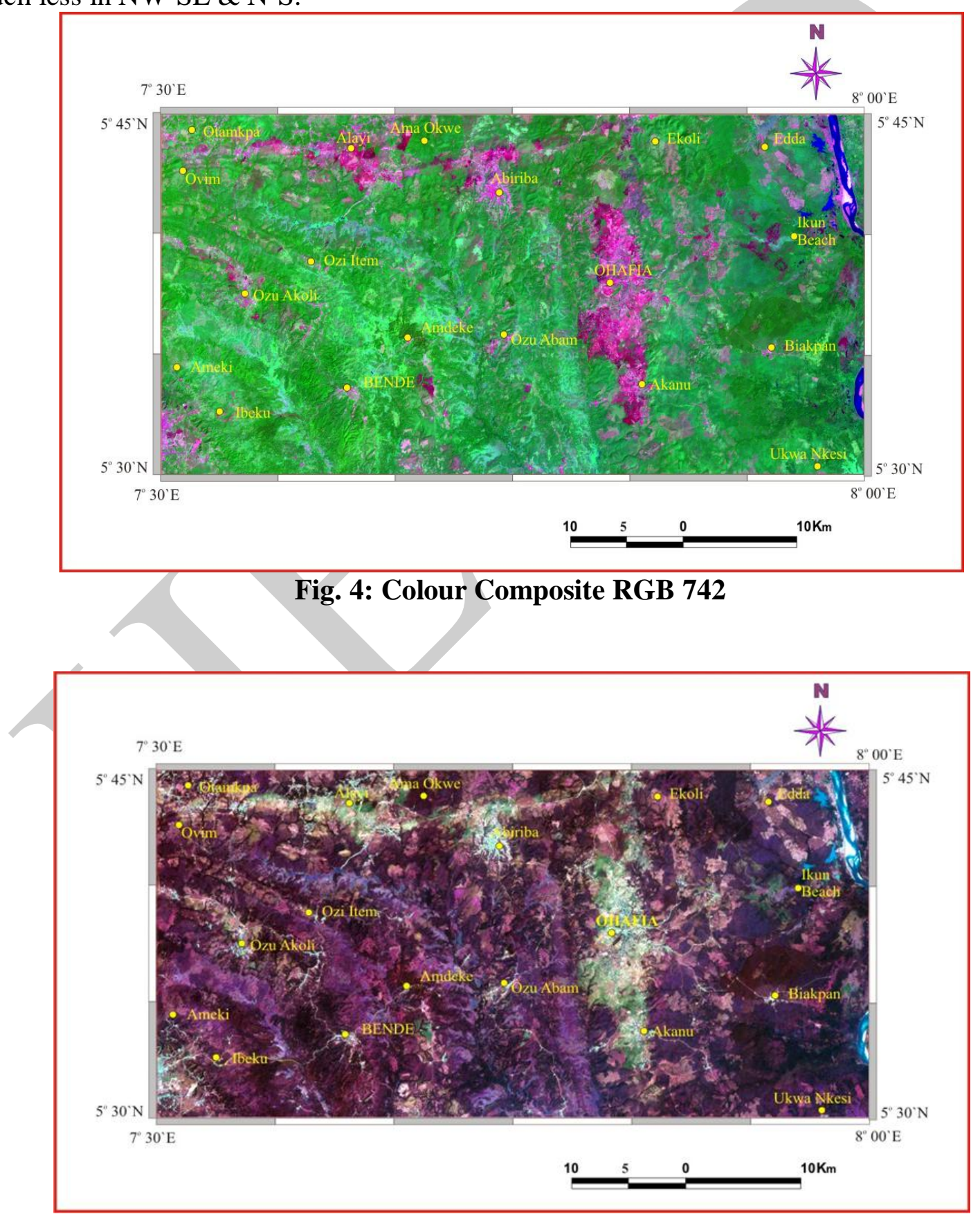

Fig. 5: Colour Composite RGB 532 


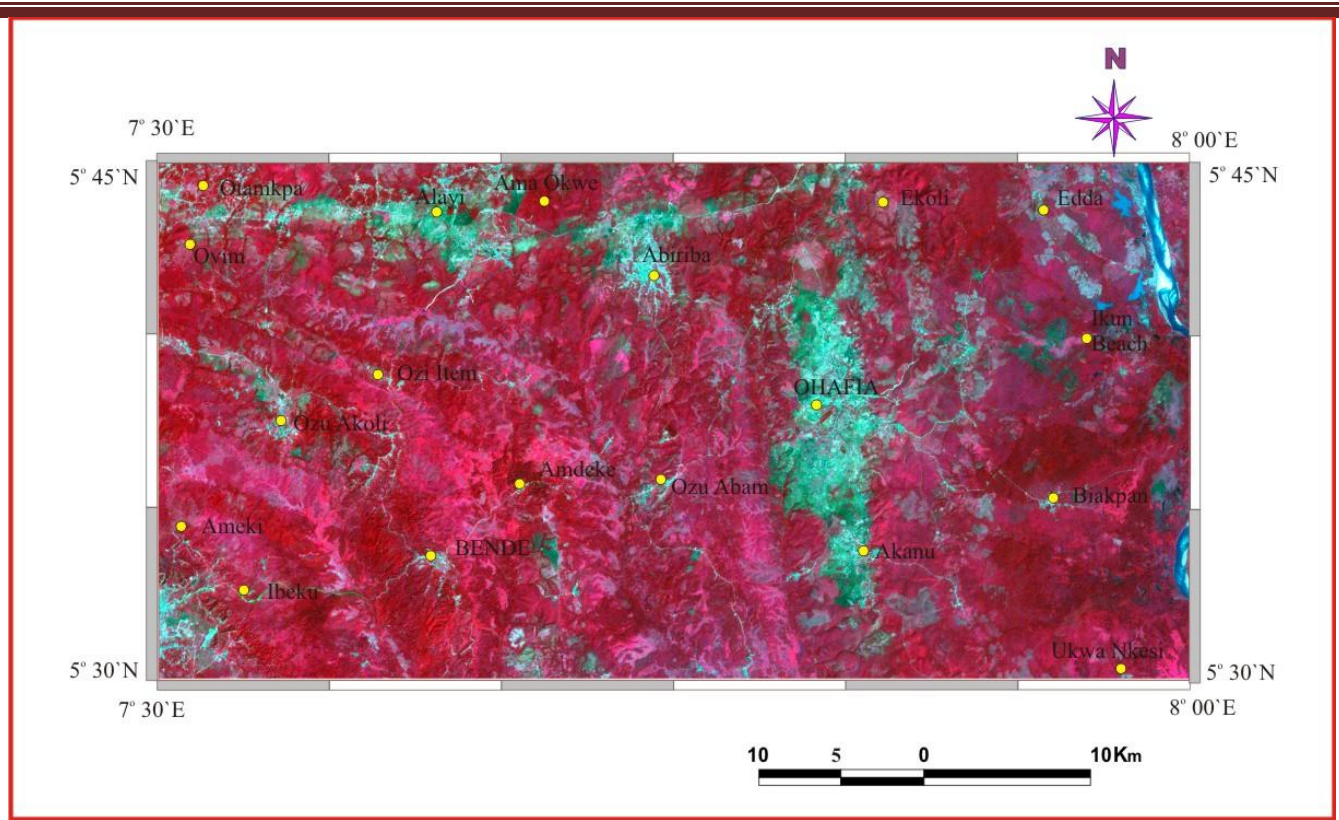

Fig. 6: Color Composite RGB 421

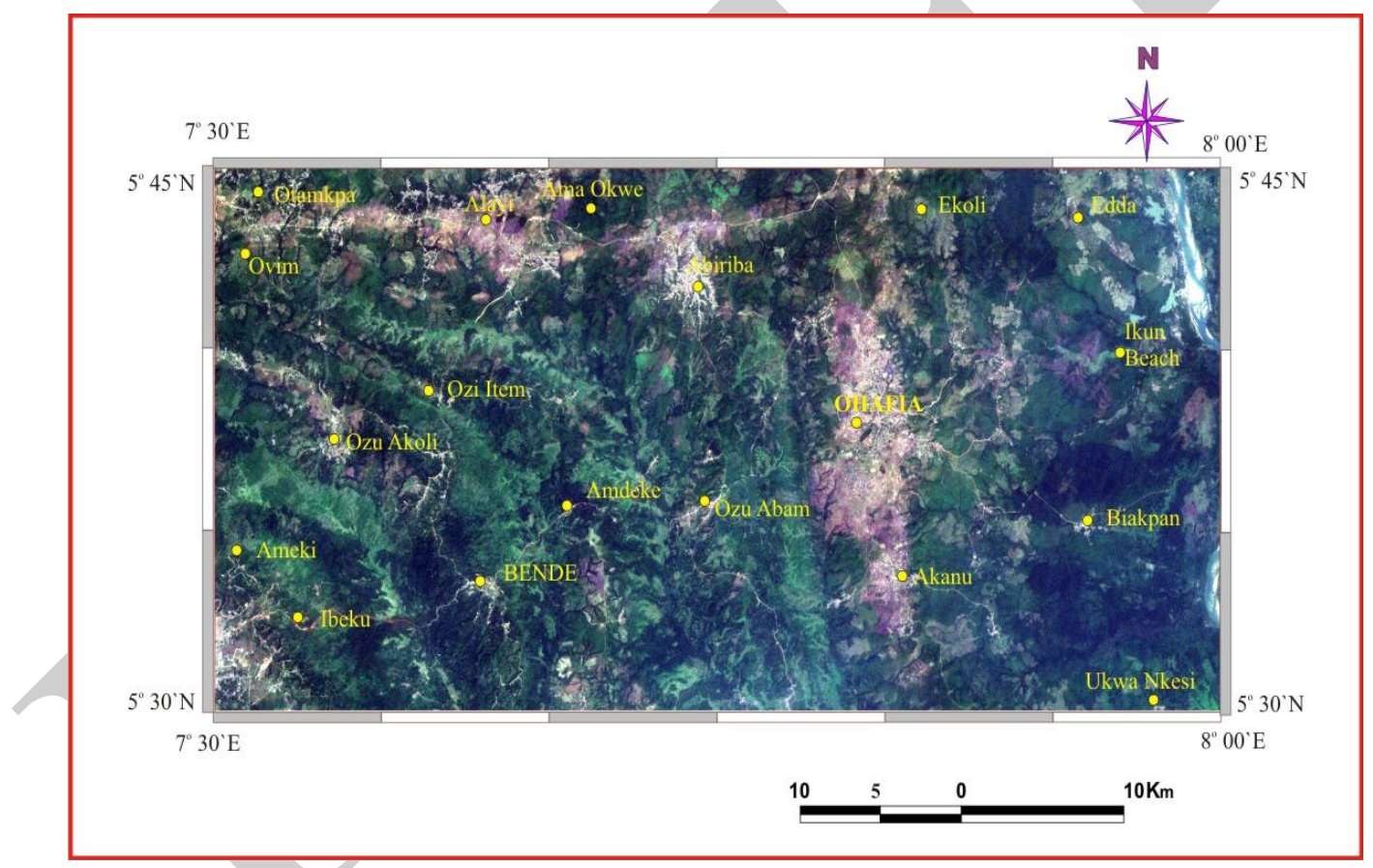

Fig. 7: Colour Composite RGB 321

Colour and colour tone are the brightness levels in digital images. The reflection of colour tones of different materials on the earth helps in distinguishing surface materials and their boundaries. In this study, there are three colour composite images with $\mathrm{RGB}, \mathrm{R}=\mathrm{Red}$, $\mathrm{G}=\mathrm{Green}, \mathrm{B}=\mathrm{Blue}$ bands of Landsat TM multispectral image respectively. The mid infrared portion of the spectrum is sensitive to active vegetation, water bodies and soil moisture. The composite image provides a naturalistic and earth view of the study area 


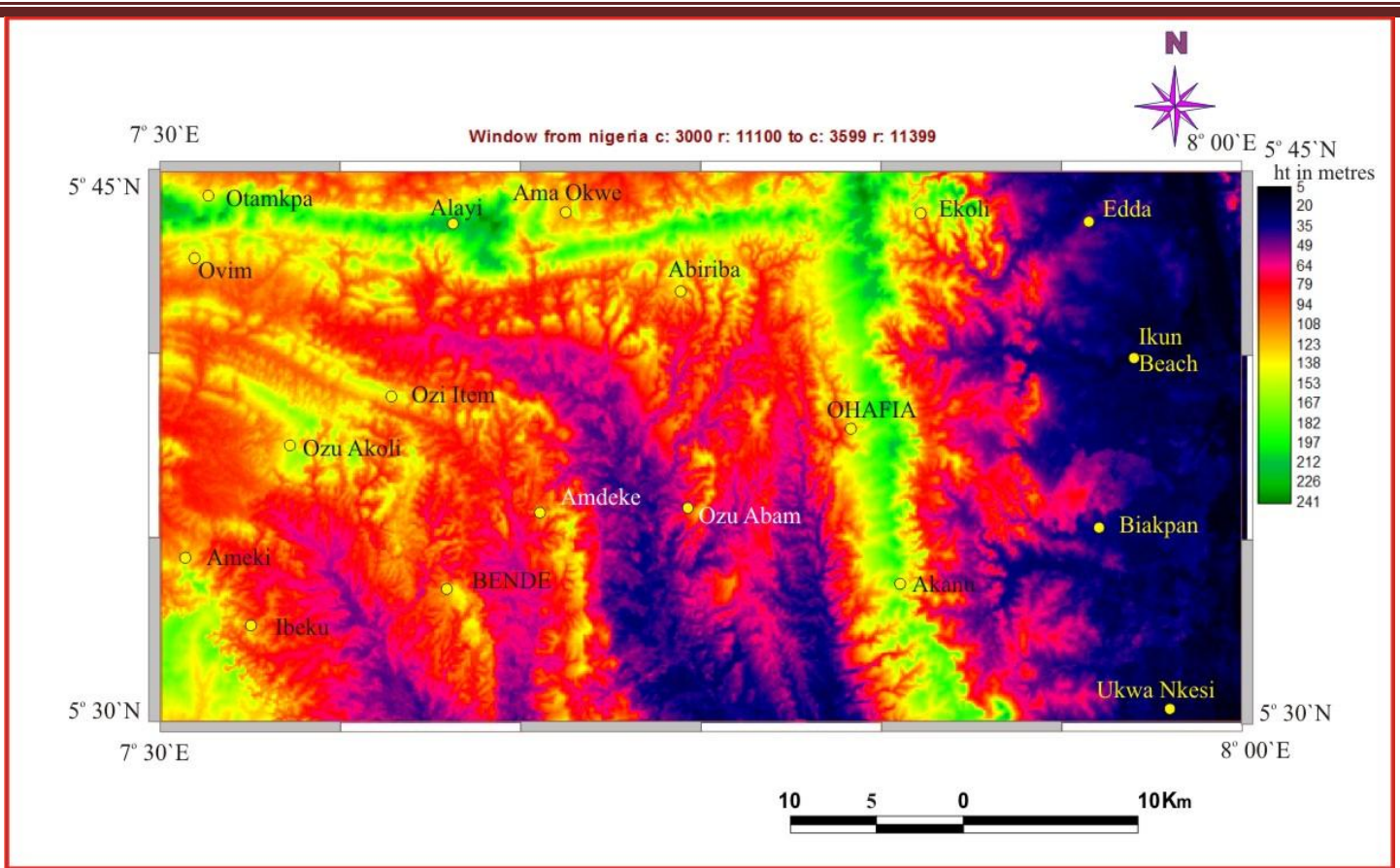

Fig. 8: Digital Elevation Model (DEM) of the area

The lineament trends corresponding to faults, geologic boundaries, folds and tectonically related joints in the area cause the ruggedness of the topography which the south eastern Nigeria has been interpreted to be a basic, associated with two major fault lines trending NESW and NW-SE (Ehirim and Ebeniro, 2006). These findings show that the area is affected by tectonic activities and the effect of these tectonic activities on the geologic formation of the area is responsible for the increasing gully and landsliding in the study area. Results from the lineament analysis revealed that the lineament trend in the area correlated well with the measured strokes of the geologic formations. Similarly, a correspondence was found to exist between the lineament map, drainage density and occurrence of gullies and landslides. Lineament features are the surface expression of fractures affecting the bedrock. It is also defined as the most favourable structural conditions in control of various mineral deposits. These features are clearly discernable on aeromagnetic maps and Landsat images. It often indicates the form and position of individual folds, faults, joints, veins, lithologic contact and other geologic features. Lineament analysis helps to reveal zones of fracture concentration and identification of surface features. Linear features as seen on satellite images are usually the results of aligned morphologic rock or topographic relief of the basement. The measured variation is interpreted in terms of the probable distribution of magnetic materials below the surface, which in turn is the basis for inferences about the probable geologic condition. Geomorphologists dealing with remote sensing applications have studied stream drainage patterns and their relationships to terrain conditions. Many have deduced different rock properties and structures using topographic relief interpretation from the imagery. They have illustrated and quantified relationships among selected rock properties, topographic and stream drainage patterns (Konecny, 2002). Stream drainage density in eroding rock landscapes can be explained by a function of rock resistance to weathering, topography and climate. Rock resistance to both chemical and mechanical weathering is an important factor in explaining drainage patterns.

In terms of topography, higher relief creates a finer textured drainage as observed in the study. It is the amount of protective vegetation cover, which can be correlated to temperature and precipitation that significantly controls erosion and drainage density. 


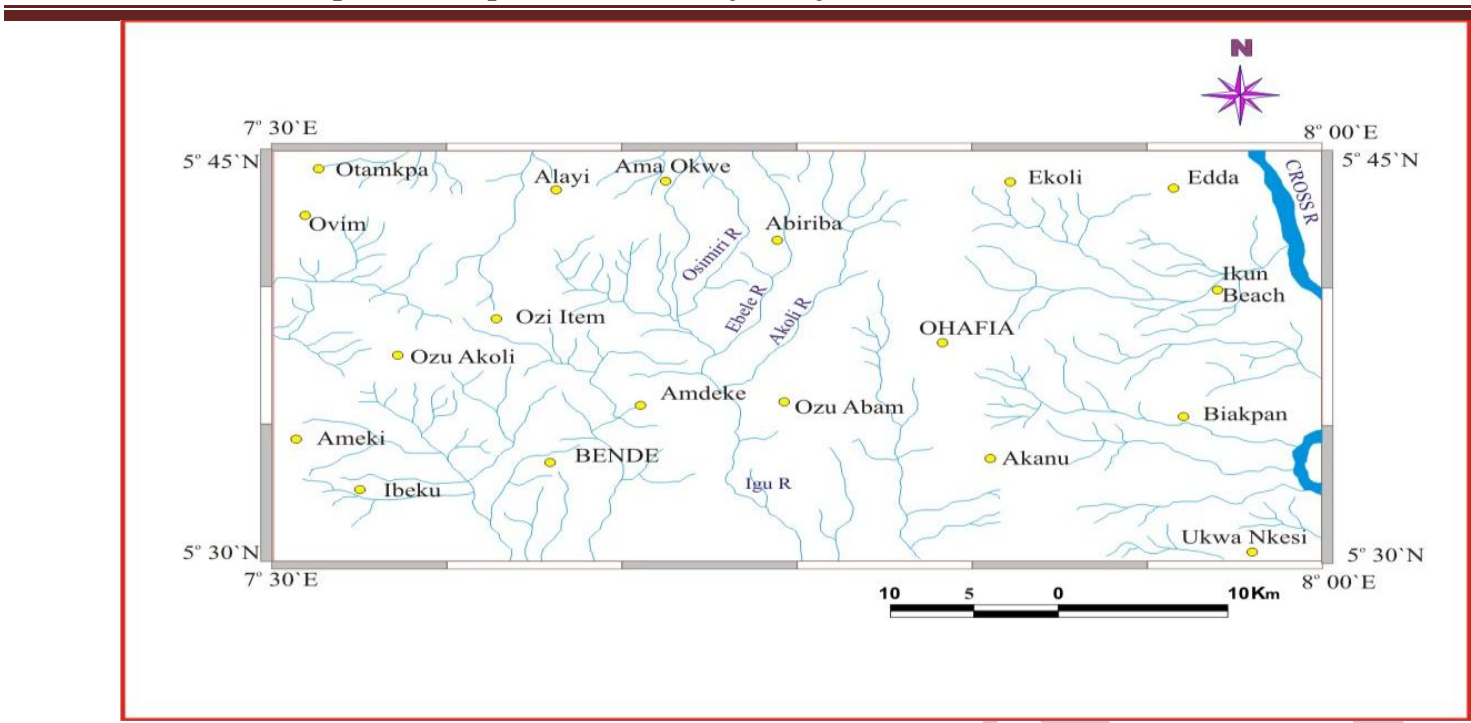

Fig. 9: Drainage Map

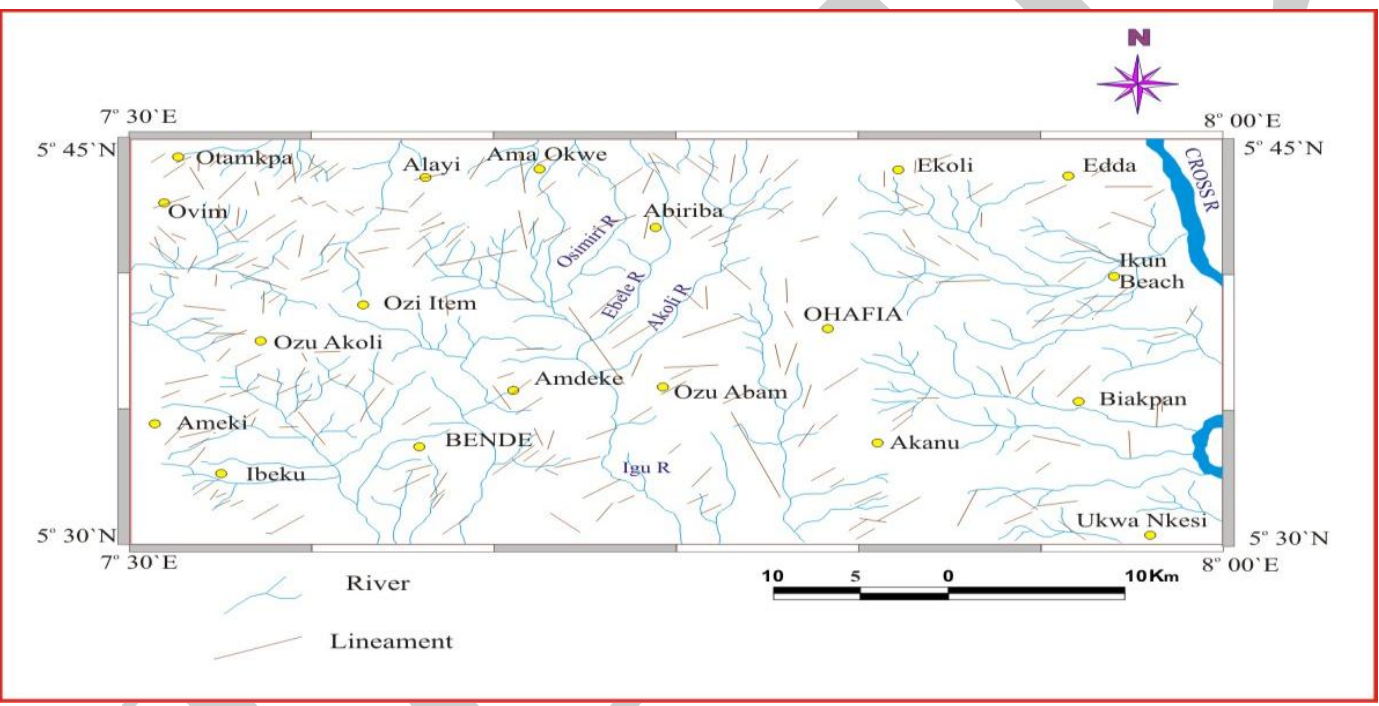

Fig.10: Lineament draped on Drainage Map

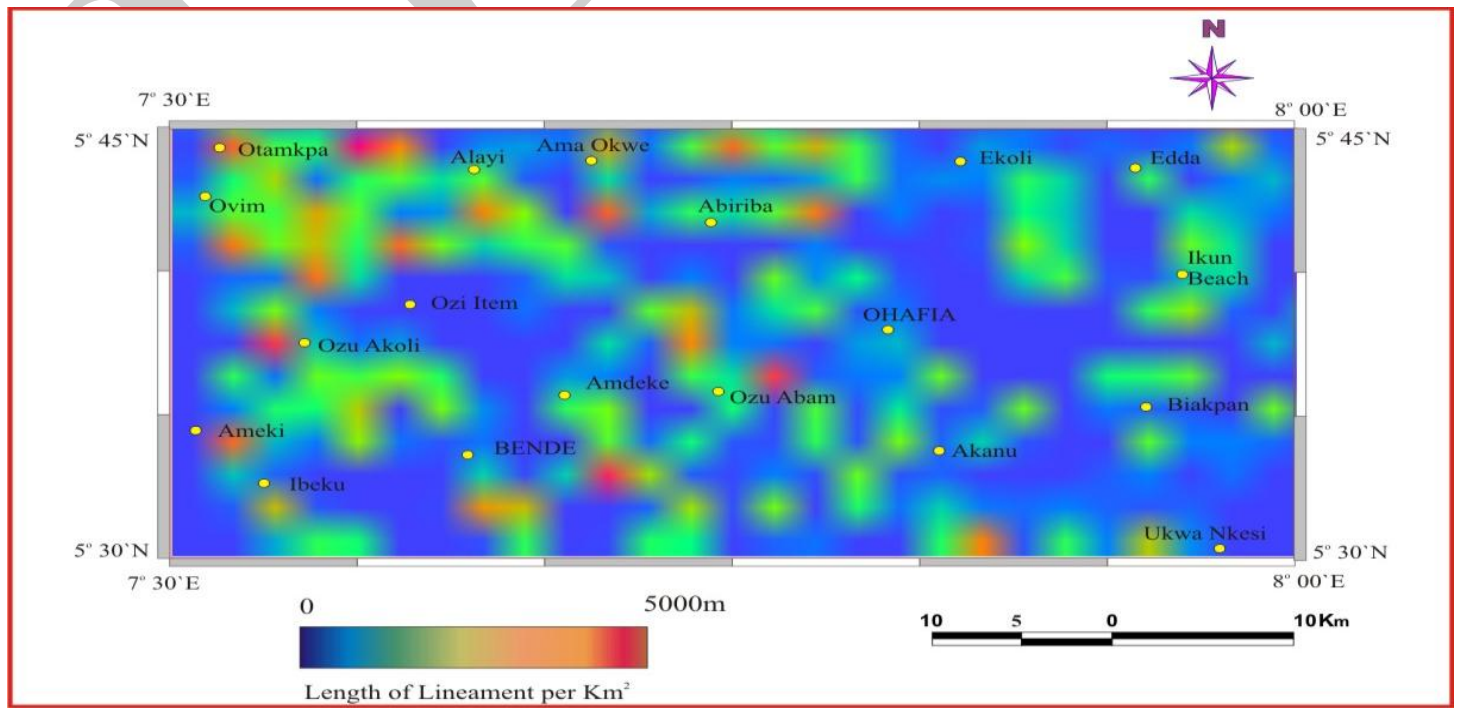

Fig. 11: Lineament Density Map of the Area 


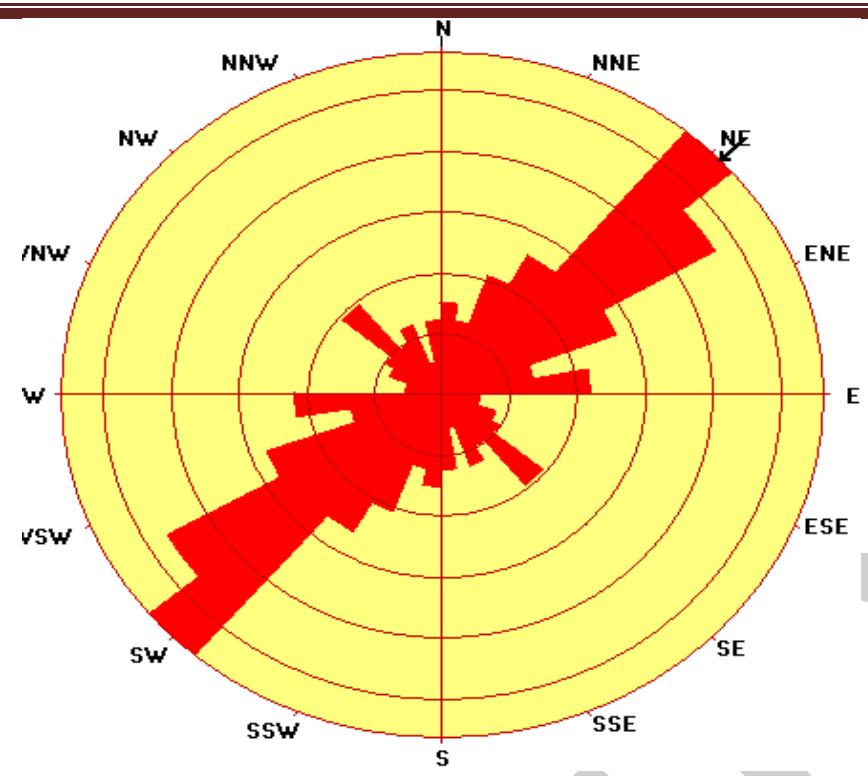

No. of Data $=243$

Sector angle $=10^{\circ}$

Scale: tick interval $=3 \%$ [7.3 data $]$

Maximum $=16.9 \%$ [41 data]

Mean Resultant direction $=047-227$

[Approx. 95\% Confidence interval $= \pm 12.5^{\circ}$ ]

Fig.12: Rose diagram showing the dominant lineament trends.

\section{CONCLUSION}

The complex nature of gully erosion and its surrounding areas also proved to be challenging for gully mapping using some of the explored vegetation indices and conventional classifiers. The study revealed that gully developments are more pronounced in areas with high terrain undulation. Adesida et al.(1977), Egboka and Okpoko (1984), Ehirim and Ebeniro (2006), Akpokodje et al. (1986) have shown that Anambra basin, Ajali-false bedded sandstone, and Nsukka Formatin is a dominant geologic formation in the area characterized by poor geotechnical properties, low vegetation cover and agricultural exposure and weakening of the soil strata authenticate the fact that significant relationships exist between vegetation types, topography, geologic formations, soil characteristics (physical and chemical) and gully formation and development in the area. The affected areas should be reclaimed by extensive afforestation and other agricultural programme. Major dewatering schemes at strategic locations should be developed and the pumped water could be treated for use. The dewatering should be on a continuous basis.

\section{RECOMMENDATION}

Areas that are still partially affected with primary gully should be checked by capping with shale and then planting grasses.

The areas affected should be reclaimed by extensive afforestation and other agricultural programmes. 


\section{REFERENCES}

1. Adesida, A.A., T.J.A. Reijers, C.S. Nwajide (1977). Sequence stratigraphic framework of the Niger Delta Basin. Vienna, Austria, AAPG International Conference and Exhibition v. 81, p.1359.

2. Akpokodje, E.G., Olorunfemi, B.N. and Etu-Efeotor, J.O. (1986). Geotechnical Properties of Soils Susceptible to Erosion in Southeastern Nigeria. Nig. Journal. App. Sci. 3 (1) pp. 81-95.

3. Bader, C. J. (Ed1962). Typical soils of the east London district. The border region, natural environment and land use in the eastern cape. Cape Town: Oxford University Press.

4. Bergsma, E. (1974). Soil erosion sequences on aerial photographs. The ITC Journal, (3), 342-376.

5. Berjak, M., Fincham, R., Liggitt, B. and Watson, H. (1986). Temporal and spatial dimensions of gully erosion in northern natal, South Africa. Commission IV of the International Society for Photogrammetry and Remote Sensing and the Remote Sensing Society, Pollock Halls, Edinburgh, Scotland.

6. Botha, G.A. (1996). Cyclical colluvial accretion on bedrock pediments in northern Natal, South Africa. Zeitschrift fur Geomorphologie, Supplement Band, 103, 85-102.

7. Botha, G.A., Wintle, A.G. and Vogel, J.C. (1994). Episodic Late Quaternarypalaeogully erosion in northern KwaZulu-Natal, South Africa. Catena, 23, 327-340.

8. Egboka, B.C.E and Nwankwor, G.I. (1982). The Hydrogeological and geotechnical parameters as Causative Agents in the Generation of Erosion in the Rain Forest Belt of Nigeria. J. Afr. Earth. Sci. 3(4), 417-425.

9. Egboka, C.E. and Okpoko, E.I. (1984). Gully erosion in the Agulu-Nanka region of Anambra State, Nigeria.

10. Ehirim, C.N. and Ebeniro, J.O. (2006). "Tectonic Trends Delineated from Drainage Lineament Analysis and Azimuthal Resistivity Survey: A case study of South Eastern Nigeria Gully Erosion Belt". Global Journal of Pure and Applied Sciences 4(1): 21-28.

11. Felix- Henningsen, P., Morgan, R.P.C., Mushala, H.M., and T. Scholten (1997). Soil erosion in Swaziland: A synthesis. Soil Technology 11(3):319-329 • October 1997.

12. Garland, G., Hoffman, T. and Todd, S. (1999). "Chapter 6: Soil degradation". In Land degradation in South Africa Edited by: Hoffman, T., Todd, S., Ntshona, Z and Turner, S. Pretoria: Dept. Env. Affairs and Tourism. (eds.).

13. Giordano A. and Marchisio C. (1991). Analysis and correlation of the existing soil erosion maps in the Mediterranean basin [J]. Quaderni di Scienza del Suolo, 3: 97132.Google Scholar.

14. Howard, A.R. (1967). Drainage Analysis in Geologic Interpretation: A Summation. The American Association of Petroleum Geologists Bulletin. V.51, No. 11 (November, 1967). P2246-2259.

15. Igbokwe, J.I., Ojiako, J.C. and Nnodu V.C. (2003). Monitoring Characterization and Controlling of Flood Water Erosions using Remote Sensing techniques. Proceeding of the Technical Session of 38th Annual conference of Nigerian Institution of Surveyors, Lokoja, Nigeria, Pp. 73-79.

16. Jensen, J. R. (2005). Introductory Digital Image Processing (3rd edition). Prentice Hall.

17. Kakembo, V. and Rowntree, M. (2003).The relationship between land use and soil erosion in the communal lands near Peddie town, Eastern Cape, South Africa. https://doi.org/10.1002/ldr.509

18. Laker, M. C. (2000). "Can Africa's soil scientists combat the threats to the continent's soil and related natural resources?". In Plenary lectures, Golden Jubilee Congress, Egyptian Soil Sci. Soc., Cairo 39-47. 
19. Liggitt, B. (1988) An investigation into soil erosion in the Mfolozi catchment.Unpubl. M.Sc. thesis, University of Natal, Pietermaritzburg.

20. Liggitt, B. \& Fincham, R. J. (1989) Gully erosion - the neglected dimension in soil erosion research. S. Afr. J. Sci. 85(1), 18-20.

21. Moore,T.R.(1979).Land Use and Erosion in The Machakos Hills.https://doi.org/10.1111/j.1467-8306.1979.tb01265.x

22. Morgan, R. P. C. (1986). "Soil Erosion and Conservation", Longman Scientific and Technical, Harlow.

23. Okeke, O. C. and Enwelu, C. (2010).Geotechnical Aspects of Soil Erosion Investigation, Control and Monitoring. UNJOTECH, Vol. 1, No.2, 2010, pp.1-2

24. Okereke, C. N., Onu, N.N., Akaolisa, C.Z., Ikoro, D.O., Ibeneme, S.I., Ubechu, B., Chinemelu, E.S. and Amadikwa, L.O. (2012). Mapping Gully Erosion Using Remote Sensing Technique: A Case Study of Okigwe Area, Southeastern Nigeria. International Journal of Engineering Research and Applications. Vol. 2, Issue 3, May-Jun 2012, pp.1955-1967.

25. Osadebe, C .C. and Akpokodje, E.G. (2007). Statistical analysis of variability in properties of soils in gully erosion sites of Agulu-Nanka-Oko area Southeastern Nigeria. Journal of Mining and Geology,43(2).pp.197-202.

26. Pimentel, D. and M. Burgess (2013).Soil Erosion Threatens Food Production. Received: 14 June 2013; in revised form: 20 July 2013/Accepted: 23 July 2013/ Published: 8August 2013

27. Poesen, J., Vandekerckhove, L. and Nachtegaele, J. (2002) Gully erosion in Dryland environments $[\mathrm{M}] / /$ Bull M J, Kirkby M J (Eds). Dryland Rivers: Hydrology and Geomorphology of Semi-Arid Channels. Chichester, UK: John Wile and Sons. Google Scholar.

28. Ritchie, J. C. (2000). Soil Erosion. USDA-ARS Hydrology Laboratory, BARe- West, Bldg-007, Beltsville, MD 20705 USA

29. Scotney, D. M. (1978) Soil erosion in Natal. In: Proc. Wildlife Soc. S. Afr. Symp. (Durban), 16-39.

30. Soil Science Society of America (1996). Subramanian, R. (2010). Surveying and Leveling. Seventh impression. Oxford University press. New Delhi, India.

31. Terrence, J. T., Foster, G.R. and Renard, K.G. (2002). Soil Erosion: Processes, Prediction, Measurement, and Control. John Wiley and Sons.

32. Van Dijk, A.I.J.M., Bruijnzeel, L.A., Rosewell, C.J. (2002). Rainfall intensity-kinetic energy relationship: A critical literature appraisal. Journal of Hydrology, 261 (1-4) (2002), pp. 1-23.

33. Weaver, A.V.B., Boucher, K.G., Boynton, R.J., Dollar, E.S.1., Erlksen, C.N., Mokoena, L.P. \& Wadeson, R., (1991). A preliminary assessment of the effects of pineapple cultivation on soil erodibility. Dohne Agric. 13, 18- 21.1

34. West Bengal Disaster Management Department (2018). Erosion. http:// www. wbdmd. gov. in/ Pages / Erosion.aspx

35. Wilkie, D. S. and J. T. Finn (1996). Remote Sensing Imagery for Natural Resources Monitoring. A Guide for First-Time Users. Methods and Cases in Conservation Science Series. xxi + 295 pp. New York, Chichester.

36. Wolf, P.R., Dewitt, B.A., and Wilkinson, B.E. (2014). Elements of Photogrammetry with Application in GIS. Fourth edition. McGraw Hill Education. 